\title{
Korelasi Antara Daya Serap Gracilaria sp. Terhadap Konsentrasi Logam Berat Cu di Media Pemeliharaan
}

\author{
Regina Amanda*, Ria Azizah Tri Nuraini, Endang Supriyantini \\ Departemen IImu Kelautan, Fakultas Perikanan dan IImu Kelautan, Universitas Diponegoro \\ JI. Prof. H. Soedarto S. H, Tembalang, Semarang, Jawa Tengah 50275 Indonesia \\ ${ }^{*}$ Corresponding author, email : reginaamanda201@gmail.com
}

\begin{abstract}
ABSTRAK: Pencemaran air terhadap lingkungan dapat menyebabkan dampak membahayakan yang dapat dirasakan oleh makhluk hidup. Salah satu logam berat yang sering mencemari air adalah logam berat tembaga $(\mathrm{Cu})$. Tujuan penelitian ini untuk mengetahui kemampuan daya serap rumput laut Gracilaria sp. terhadap logam berat Cu dan pertumbuhannya. Penelitian ini menggunakan metode eksperimental laboratoris dengan Rancangan Acak Lengkap (RAL) dengan menggunakan 4 perlakuan penambahan konsentrasi $\mathrm{Cu}$, yaitu kontrol (0,54 ppm, sesuai dengan konsentrasi $\mathrm{Cu}$ pada air laut), 3 ppm, 6 ppm, 9 ppm dengan 3 kali pengulangan. Pengukuran kandungan logam Cu terhadap Gracilaria sp. dengan menggunakan Atomic Absorpsion Spektofotometri (AAS). Hasil penelitian menunjukkan bahwa penyerapan logam berat Cu tertinggi terdapat pada konsentrasi 9 ppm, yaitu sebesar 3,63 ppm dan terendah pada kontrol yaitu sebesar 0,27 ppm.. Pertumbuhan Gracilaria sp. tertinggi terdapat pada perlakuan kontrol dengan pertambahan berat sebesar 209,2 gram dan terendah pada konsentrasi 9 ppm, yaitu sebesar 162,9 gram. Semakin tinggi konsentrasi $\mathrm{Cu}$ yang diberikan maka semakin rendah pertumbuhan Gracilaria sp.
\end{abstract}

Kata kunci : Gracilaria sp.; Logam berat; Tembaga (Cu); Daya Serap

\section{Correlation Between the Absorption Capacity of Gracilaria sp. Against Heavy Metal Cu Concentration in Maintenance Media}

ABSTRACT: Water pollution to the environment can cause dangerous impacts that can be felt by living things. One of the heavy metals that often pollutes water is the heavy metal copper (Cu). The purpose of this study was to determine the absorption capacity of Gracilaria sp. to the heavy metal $\mathrm{Cu}$ and its growth. This study used a laboratory experimental method with a completely randomized design (RAL) using 4 additional treatments of Cu concentration, namely control (0.54 ppm, according to the Cu concentration in seawater), 3 ppm, 6 ppm, 9 ppm with 3 repetitions. Measurement of $\mathrm{Cu}$ metal content against Gracilaria sp. by using Atomic Absorption Spectophotometry (AAS). The results showed that the highest absorption of heavy metal Cu was at a concentration of 9 ppm, which was $3.63 \mathrm{ppm}$ and the lowest was 0,27 ppm in control.. The Growth of Gracilaria sp. The highest was found in the control treatment with a weight gain of 209.2 grams and the lowest was at a concentration of 9 ppm, which was 162.9 grams. The higher the concentration of $\mathrm{Cu}$ given, the lower the growth of Gracilaria sp.

Keywords: Gracilaria sp.; Heavy Metal; Copper (Cu); Absorption

\section{PENDAHULUAN}

Pencemaran merupakan salah satu permasalahan yang dihadapi di masa sekarang. Pencemaran air terhadap lingkungan dapat menyebabkan dampak yang membahayakan yang dapat di rasakan oleh makhluk hidup. Faktor utama penyebab pencemaran lingkungan adalah limbah industri, limbah domestik, serta limbah sarana rekreasi dan pariwisata. Limbah yang dihasilkan oleh kegiatan industri yang tanpa diolah terlebih dahulu menjadi penyebab pencemaran lingkungan yang sangat besar karena limbah yang dihasilkan dalam skala besar (Lestari dan Edward, 2004).

Logam Cu merupakan logam yang dihasilkaan oleh industri. Logam Cu digolongkan kedalam 
logam berat esensial dalam konsentrasi yang sangat kecil, apabila pada konsentrasi tinggi logam $\mathrm{Cu}$ akan menjadi racun bagi makhluk hidup. Logam berat $\mathrm{Cu}$ mengkontaminasi lingkungan air dapat memberikan pengaruh buruk pada biota dengan terhambatnya metabolisme karena terjadi kerusakan dan penurunan kerja enzim. Selain itu logam berat $\mathrm{Cu}$ juga memberikan efek negative pada tanaman jika terakumulasi terlalu tinggi (Elawati et al., 2016). Menurut Samsundari dan Perwira (2011) rumput laut sebagai bioindicator pencemaran yang efisien untuk menduga pencemaran logam berat.

Rumput laut Gracilaria sp. mempunyai kemampuan menyerap logam berat $\mathrm{Pb}, \mathrm{Cu}$ dan $\mathrm{Cd}$. Kemampuan menyerap logam berat tersebut diduga karena Gracilaria mengandung polisakarida yang terdapat pada dinding selnya sehingga Gracilaria mampu mengikat ion logam berat yang ada disekitarnya dan membentuk senyawa kompleks dengan zat-zat organik yang terdapat dalam thallus (Yulianto et al., 2006; Raya \& Ramlah, 2012). Menurut Suardika et al. (2017) rumput laut ditemukan dapat membersihkan polutan yang cukup efektif dari pembuangan limbah industri seperti logam berat, rumput laut mampu menyerap logam berat dalam air yang dibuang dari industri sebesar $95 \%$.

Berdasarkan uraian tersebut, maka dilakukan penelitian tentang daya serap Gracilaria yang diharapkan dapat memberikan informasi tentang potensi Gracilaria sp. dalam penyerapan logam $\mathrm{Cu}$ di media pemeliharaan. Tujuan penelitian ini adalah untuk mengetahui pertumbuhan dan kemampuan daya serap Gracilaria sp. terhadap logam berat $\mathrm{Cu}$ dengan konsentrasi yang berbeda.

\section{MATERI DAN METODE}

Materi yang digunakan pada penelitian ini adalah rumput laut Gracilaria sp. yang berasal dari budidaya rumput laut di Balai Besar Perikanan Budidaya Air Payau (BBPBAP) Jepara. Sebelum dilakukan penelitian, Gracilaria sp. diaklimatisasi selama 7 hari agar beradaptasi dengan lingkungan yang baru. Wadah uji yang digunakan adalah akuarium kaca berukuran 50 $\mathrm{cm} \times 30 \mathrm{~cm} \times 35 \mathrm{~cm}$ sebanyak 12 buah. Masing-masing akuarium diisi air laut sebanyak $30 \mathrm{~L}$ dengan salinitas 25 ppt (Widyorini, 2010; Atmadja et al., 2012), dan tiap akuarium membutuhkan Gracilaria sp. sebanyak 400 gram yang dibagi menjadi dua ikatan, masing-masing 200 gram untuk sampel yang akan dianalisis absorpsinya dan 200 gram untuk pengukuran pertumbuhan. Media pemeliharaan ditambah dengan logam berat $\mathrm{Cu}$ yang berasal dari tembaga (II) sulfat pentahidrat $\left(\mathrm{CuSO}_{4} .5 \mathrm{H}_{2} \mathrm{O}\right)$.

Metode yang digunakan yaitu eksperimental laboratoris menggunakan rancangan acak lengkap (RAL) dengan menggunakan 4 perlakuan, yang terdiri dari $A$ (kontrol) $=0,54 \mathrm{ppm}$, sesuai dengan konsentrasi $\mathrm{Cu}$ pada air laut, $\mathrm{B}=$ konsentrasi $\mathrm{Cu} 3 \mathrm{ppm}, \mathrm{C}=$ konsentrasi $\mathrm{Cu} 6$ ppm, dan $\mathrm{D}=$ konsentrasi Cu 9 ppm.

Parameter yang diukur meliputi, pengukuran berat basah, pertumbuhan mutlak, laju pertumbuhan spesifik (SGR), kandungan logam berat yang dilakukan setiap minggu sekali selama 28 hari, dan parameter kualitas air pada media, seperti suhu,salinitas, pH,DO diukur setiap hari selama 28 hari masa pemeliharaan. Analisis pengukuran konsentrasi Cu dilakukan dengan menggunakan Atomic Absorption Spectrophotometer (AAS).

\section{HASIL DAN PEMBAHASAN}

Berdasarkan hasil analisa menunjukkan bahwa dengan penambahan konsentrasi logam $\mathrm{Cu}$ yang berbeda selama waktu pemeliharaan 28 hari akan mempengaruhi konsentrasi logam Cu pada rumput laut Gracilaria sp. Kemampuan daya serap Gracilaria sp. terhadap logam $\mathrm{Cu}$ menunjukkan pengaruh yang nyata antar perlakuan $(p<0,05)$. Hasil uji korelasi memperlihatkan adanya hubungan antara penambahan konsentrasi logam $\mathrm{Cu}$ dengan penyerapan logam $\mathrm{Cu}$ oleh Gracilaria sp. dengan nilai korelasi sebesar -0,429. Pernyataan ini dapat ditunjukkan pada Tabel 1, semakin ditingkatkan konsentrasi Cu maka semakin tinggi pula penyerapan Gracilaria terhadap logam $\mathrm{Cu}$. Peningkatan ini terjadi pada semua perlakuan, penyerapan logam $\mathrm{Cu}$ tertinggi oleh Gracilaria terjadi pada perlakuan D (9 ppm) yaitu sebesar 3,63 ppm, sedangkan terendah terdapat pada kontrol yaitu sebesar 1,24 ppm. Hasil ini seiring dengan konsentrasi 
logam $\mathrm{Cu}$ yang ada di dalam media pemeliharaan, yaitu konsentrasi logam $\mathrm{Cu}$ dalam media semakin berkurang hasil terendah terdapat pada perlakuan $\mathrm{D}(9 \mathrm{ppm})$ yaitu sebesar $0,36 \mathrm{ppm}$ (Tabel 2). Hal ini membuktikan bahwa adanya proses penyerapan logam $\mathrm{Cu}$ yang dilakukan oleh rumput laut Gracilaria sp. Sesuai dengan pendapat Raya dan Ramlah (2012), bahwa konsentrasi logam berat yang ada dalam media pemeliharaan akan mempengaruhi jumlah logam berat yang diakumulasi oleh rumput laut. Kemampuan penyerapan logam Cu oleh rumput laut Gracilaria sp. diduga karena adanya kandungan polisakarida dan protein yang ada pada dinding sel rumput laut sehingga mampu mengikat ion logam berat dan membentuk senyawa kompleks dengan zatzat organik yang terdapat dalam thallus (Yulianto et al., 2006; Das et al., 2008; Raya \& Ramlah, 2012). Proses penyerapan logam $\mathrm{Cu}$ oleh Gracilaria diduga dipengaruhi juga oleh bentuk thallus. Menurut Nduka (2012), bahan yang memiliki diameter lebih kecil memiliki tingkat penyerapan yang lebih tinggi dibandingkan dengan bahan (adsorben) yang berdiameter besar. Ihsan et al. (2015), menyatakan bahwa Gracilaria sp. memiliki bentuk thallus seperti tulang rawan dan bercabang-cabang sehingga memungkinkan mempunyai kemampuan menyerap logam berat lebih banyak dan lebih efektif. Dijelaskan pula oleh Angkasa et al. (2011), bahwa thallus Gracilaria berbentuk silindris dengan diameter 0,5 hingga $4,0 \mathrm{~mm}$ dan membentuk rumpun dengan jenis percabangan yang tidak teratur. Supriyantini et al. (2018), menyatakan bahwa proses perpindahan massa $\mathrm{Cu}$ secara difusi dan osmosis akan mempengaruhi proses penyerapan logam $\mathrm{Cu}$ Gracilaria, dimana konsentrasi yang tinggi akan berpindah ke media dengan konsentrasi yang rendah.

Tabel 1, terlihat bahwa hasil penyerapan logam $\mathrm{Cu}$ oleh Gracilaria semakin meningkat seiring dengan penambahan logam Cu dalam media, hal ini mengindikasikan bahwa rumput laut Gracilaria pada kondisi belum jenuh (belum tercapai keadaan setimbang), diduga sisi aktif pada rumput laut Gracilaria masih mempunyai kemampuan dalam mengikat ion logam $\mathrm{Cu}$. Menurut Simatupang et al. (2017), bila permukaan sudah jenuh atau mendekati jenuh terhadap adsorbat, dapat terjadi dua hal yaitu terbentuk lapisan adsorpsi kedua dan seterusnya di atas adsorbat yang telah terikat di permukaan (adsorpsi multilayer), atau tidak terbentuk lapisan kedua dan seterusnya sehingga adsorbat yang belum teradsorpsi berdifusi keluar pori dan kembali ke arus fluida.

Menurut Yong et al. (2017) gugus aktif dari alga seperti karboksil, sulfat, sulfonat, dan amina mempunyai kemampuan dalam mengikat ion logam, sehingga baik digunakan untuk biosorben (Figueira et al., 2000; Davis et al., 2000; Davis et al., 2003; Rodenas de la Rocha et al., 2009). Meningkatnya penyerapan logam $\mathrm{Cu}$ oleh Gracilaria diduga juga karena proses metabolisme secara biologi melalui sintesis fitokelatin oleh thallus pada rumput laut berlangsung dalam jumlah lebih banyak, sehingga Gracilaria sp. bisa tetap bertahan hidup di dalam media tersebut dan tetap terus melakukan penyerapan. Sesuai dengan pendapat Nasuha et al. (2014), bahwa logam berat yang terakumulasi pada thallus G. gigas akan diminimumkan pengaruhnya dengan lokalisasi pada vakuola dan akan membentuk zat kelat dengan bantuan enzim phytochelatin sehingga tidak menghambat laju metabolismenya.

Hasil penelitian menunjukkan bahwa pertumbuhan Gracilaria sp. pada setiap perlakuan memiliki hasil yang berbeda. Pada perlakuan A (kontrol) mengalami pertumbuhan setiap minggunya, hal ini memperlihatkan bahwa perlakuan A (kontrol) mengalami pertambahan berat

Tabel 1. Konsentrasi Logam Cu dalam Rumput Laut Gracilaria sp. setelah 28 Hari Pemeliharaan dengan Konsentrasi yang Berbeda

\begin{tabular}{cccccc}
\hline \multirow{2}{*}{ Perlakuan } & \multicolumn{5}{c}{ Konsentrasi Logam Cu (ppm) Gracilaria sp. Hari ke- } \\
\cline { 2 - 6 } & 0 & 7 & 14 & 21 & 28 \\
\hline A & $0,8 \pm 0,00$ & $0,27 \pm 0,31$ & $0,41 \pm 0,18$ & $0,81 \pm 0,05$ & $1,24 \pm 0,29$ \\
B & $0,8 \pm 0,00$ & $0,77 \pm 0,62$ & $0,78 \pm 0,75$ & $1,35 \pm 0,45$ & $1,30 \pm 0,42$ \\
C & $0,8 \pm 0,00$ & $1,50 \pm 0,31$ & $1,01 \pm 0,25$ & $1,04 \pm 0,34$ & $1,66 \pm 0,16$ \\
D & $0,8 \pm 0,00$ & $1,31 \pm 0,22$ & $2,74 \pm 0,23$ & $2,64 \pm 0,45$ & $3,63 \pm 0,32$ \\
\hline
\end{tabular}

Keterangan: $\mathrm{A}=$ Kontrol; $\mathrm{B}=$ Konsentrasi $\mathrm{Cu} 3 \mathrm{ppm}$; $\mathrm{C}=$ Konsentrasi $\mathrm{Cu} 6$ ppm; $\mathrm{D}=$ Konsentrasi Cu 9 ppm basah, dengan berat tertinggi sebesar 209,2 gram pada hari ke 28 , sedangkan penurunan berat 
basah terendah terdapat pada perlakuan $D(9 \mathrm{ppm})$ dengan berat basah sebesar $162,9 \mathrm{gram}$. Penurunan berat basah juga terjadi pada perlakuan B (3 ppm) dan C (6 ppm). Penurunan berat basah diduga karena Gracilaria sp. terlalu banyak menyerap logam $\mathrm{Cu}$ yang ada pada media pemeliharaan sehingga mengganggu metabolisme dan menghambat pertumbuhan rumput laut tersebut. Supriyantini et al. (2018), menyatakan bahwa Cu merupakan mikronutrien yang esensial bagi tubuh, tetapi apabila jumlahnya melebihi batas tolerir suatu organisme maka akan bersifat toksik. Menurut Yulianto et al. (2006), bahwa semakin banyak mengakumulasi logam berat maka semakin tinggi tingkat kematiannya. Hal ini dibuktikan dengan berkurangnya berat basah yang terjadi pada pertumbuhan selama 28 hari masa pemeliharaan (Tabel 3).

Hasil pertumbuhan Gracilaria sp. juga didukung dengan hasil pertumbuhan mutlak dan laju pertumbuhan (SGR) pada tiap perlakuan (Tabel 4 dan 5). Hasil pertumbuhan mutlak dan laju pertumbuhan (SGR) tertinggi terdapat pada perlakuan A (kontrol) yaitu sebesar 7,57 gram dan $0,10 \%$. Sedangkan pada perlakuan B (3 ppm), C (6 ppm), dan D (9 ppm) tidak mengalami pertumbuhan pada Gracilaria sp. hal ini ditandai adanya tanda negatif (-) pada hasil pertumbuhan mutlak dan laju pertumbuhan spesifik. Menurut Ihsan et al (2015), beberapa gejala kelebihan logam berat akan mengakibatkan pengurangan dan penghambatan proses penyerapan nutrient oleh tanaman, sehingga kehidupannya menjadi terhambat. Terhambatnya proses metabolisme ini diduga adanya gangguan fungsi enzim dan rusaknya struktur molekul enzim sehingga akan terjadi kerusakan anatomi makroalga. Hasil pertumbuhan mutlak dan laju pertumbuhan spesifik terlihat pada (Tabel 4 dan 5).

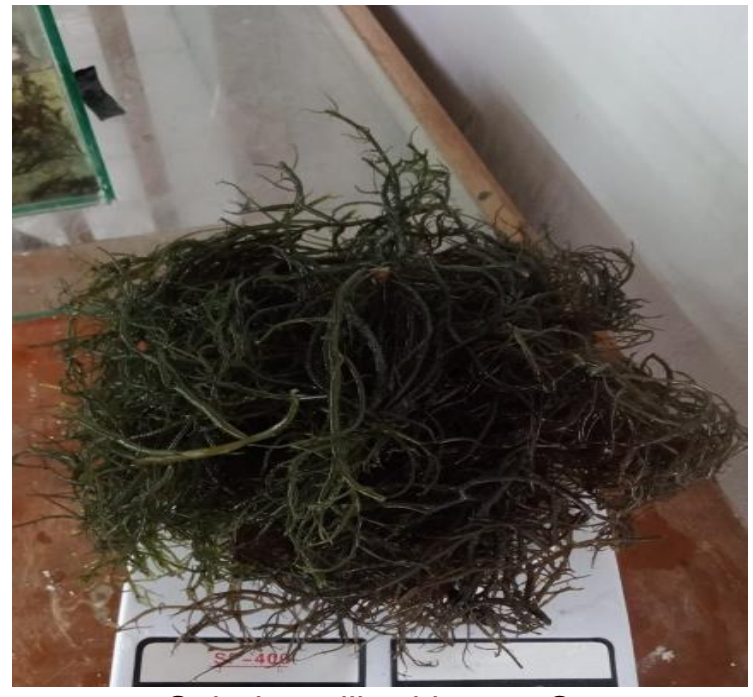

Sebelum diberi logam $\mathrm{Cu}$

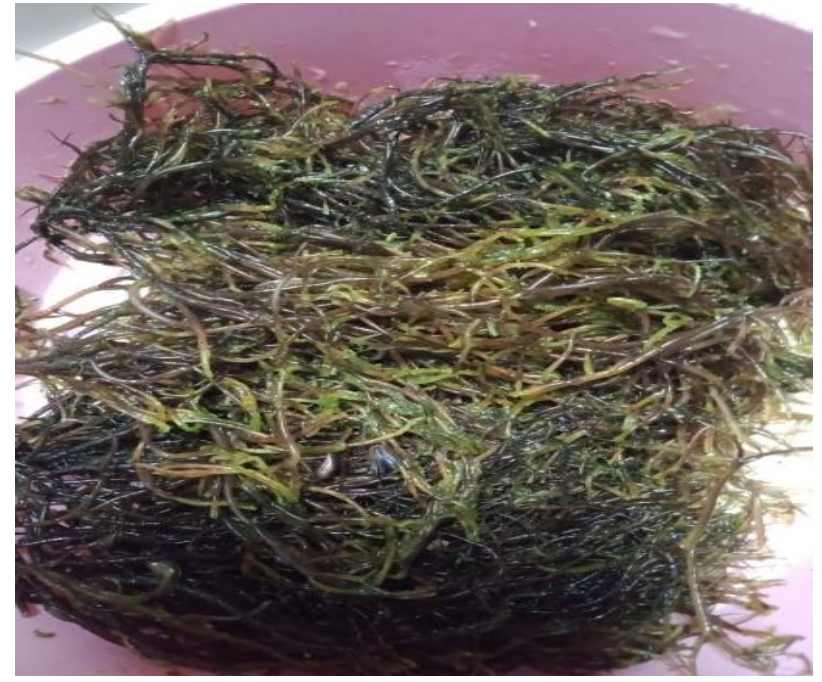

Sesudah diberi logam $\mathrm{Cu}$

Gambar 1. Kondisi Gracilaria sp. yang terpapar logam $\mathrm{Cu}$

Tabel 2. Konsentrasi Logam $\mathrm{Cu}$ dalam Media Rumput Laut Gracilaria sp Setelah 28 Hari Pemeliharaan dengan Konsentrasi yang Berbeda

\begin{tabular}{cccccc}
\hline \multirow{2}{*}{ Perlakuan } & \multicolumn{5}{c}{ Konsentrasi logam Cu $(\mathrm{ppm})$ pada Hari ke- } \\
\cline { 2 - 6 } & 0 & 7 & 14 & 21 & 28 \\
\hline A & $0,54 \pm 0,00$ & $0,03 \pm 0,10$ & $0,03 \pm 0,01$ & $0,13 \pm 0,16$ & $0,39 \pm 0,10$ \\
B & $3,04 \pm 0,00$ & $0,18 \pm 0,08$ & $0,28 \pm 0,09$ & $0,33 \pm 0,13$ & $0,38 \pm 0,10$ \\
C & $6,06 \pm 0,00$ & $0,19 \pm 0,02$ & $0,22 \pm 0,02$ & $0,50 \pm 0,08$ & $0,43 \pm 0,09$ \\
D & $9,04 \pm 0,00$ & $0,32 \pm 0,32$ & $0,44 \pm 0,06$ & $0,48 \pm 0,08$ & $0,36 \pm 0,07$ \\
\hline
\end{tabular}

Keterangan: $\mathrm{A}=$ Kontrol; $\mathrm{B}=$ Konsentrasi $\mathrm{Cu} 3$ ppm; $\mathrm{C}=$ Konsentrasi Cu 6 ppm; $\mathrm{D}=$ Konsentrasi $\mathrm{Cu} 9 \mathrm{ppm}$ 
Tabel 3. Berat Basah Gracilaria sp. (gram) pada Media yang Mengandung Konsentrasi Cu yang Berbeda selama 28 Hari Masa Pemeliharaan

\begin{tabular}{cccccc}
\hline \multirow{2}{*}{ Perlakuan } & \multicolumn{5}{c}{ Berat Basah (gram) Gracilaria sp. pada Hari ke- } \\
\cline { 2 - 6 } & 0 & 7 & 14 & 21 & 28 \\
\hline A & $200 \pm 0,00$ & $205,1 \pm 0,43$ & $207,4 \pm 0,50$ & $208,5 \pm 0,49$ & $209,2 \pm 0,55$ \\
B & $200 \pm 0,00$ & $192,5 \pm 0,35$ & $188,9 \pm 1,18$ & $181,2 \pm 1,60$ & $171,8 \pm 2,31$ \\
C & $200 \pm 0,00$ & $192,8 \pm 0,6$ & $184,8 \pm 1,48$ & $175,9 \pm 1,82$ & $169,2 \pm 1,31$ \\
D & $200 \pm 0,00$ & $192,1 \pm 0,3$ & $183,7 \pm 1,83$ & $173,1 \pm 2,45$ & $162,9 \pm 1,05$ \\
\hline
\end{tabular}

Keterangan: $\mathrm{A}=$ Kontrol; $\mathrm{B}=$ Konsentrasi $\mathrm{Cu} 3$ ppm; $\mathrm{C}=$ Konsentrasi Cu 6 ppm; $\mathrm{D}=$ Konsentrasi $\mathrm{Cu} 9$ ppm

Tabel 4. Pertumbuhan Mutlak Gracilaria sp. pada Media yang Mengandung Konsentrasi Cu yang Berbeda selama 28 Hari Masa Pemeliharan

\begin{tabular}{cccc}
\hline Perlakuan & Berat Awal (W0) & Berat Akhir (Wt) & Pertumbuhan Mutlak (G) \\
\hline A & $200,00 \pm 0,00$ & $207,57 \pm 1,80$ & $7,57 \pm 1,80$ \\
B & $200,00 \pm 0,00$ & $183,61 \pm 9,17$ & $-7,04 \pm 2,43$ \\
C & $200,00 \pm 0,00$ & $180,67 \pm 10,31$ & $-7,7 \pm 0,99$ \\
D & $200,00 \pm 0,00$ & $177,95 \pm 12,70$ & $-9,27 \pm 1,34$ \\
\hline
\end{tabular}

Keterangan: $\mathrm{A}=$ Kontrol; $\mathrm{B}=$ Konsentrasi $\mathrm{Cu} 3$ ppm; $\mathrm{C}=$ Konsentrasi $\mathrm{Cu} 6$ ppm; $\mathrm{D}=$ Konsentrasi $\mathrm{Cu} 9$ ppm

Tabel 5. Laju Pertumbuhan Spesifik (SGR) Gracilaria sp. pada Media yang Mengandung Konsentrasi Cu yang Berbeda selama 28 Hari Masa Pemeliharaan

\begin{tabular}{cccc}
\hline Perlakuan & Ln W0 & Ln Wt & SGR (\%) \\
\hline A & $5,30 \pm 0,00$ & $5,33 \pm 0,58$ & $0,10 \pm 0,03$ \\
B & $5,30 \pm 0,00$ & $5,21 \pm 2,21$ & $-0,32 \pm 0,33$ \\
C & $5,30 \pm 0,00$ & $5,19 \pm 2,33$ & $-0,39 \pm 0,38$ \\
D & $5,30 \pm 0,00$ & $5,18 \pm 2,54$ & $-0,42 \pm 0,42$ \\
\hline
\end{tabular}

Keterangan: $\mathrm{A}=$ Kontrol; $\mathrm{B}=$ Konsentrasi $\mathrm{Cu} 3$ ppm; $\mathrm{C}=$ Konsentrasi $\mathrm{Cu} 6$ ppm; $\mathrm{D}=$ Konsentrasi $\mathrm{Cu} 9$ ppm

Pengamatan visual pada Gracilaria sp. memperlihatkan bahwa pada perlakuan A (kontrol) tidak terjadi perubahan warna. Berbeda dengan B (3 ppm), C (6 ppm), dan D (9 ppm) dengan penambahan $\mathrm{Cu}$ terlihat perbedaan yang jelas pada warna dan tekstur thallus. Warna thallus yang awalnya coklat berubah menjadi warna hijau muda (Gambar 1) dan teksturnya -non elastis, mudah rapuh, dan berlendir. Menurut Yulianto et al (2006), bahwa ketidakmampuan tanaman dalam mentoleransi konsentrasi logam berat akan mengganggu sifat tanaman seperti thallus yang menjadi non elastis dan ujung thallus berwarna kekuningan. Hal ini diduga adanya proses gangguan metabolisme pada Gracilaria sp. akibat akumulasi Cu dan lamanya waktu pemaparan yang dipengaruhi oleh mekanisme penyerapan $\mathrm{Cu}$ yang ada pada media pemeliharaan. Ketidakmampuan dalam mentolerir adanya akumulasi Cu menyebabkan gangguan fisiologis yang mengakibatkan kerusakan organ sel tumbuhan (Supriyantini et al., 2018).

\section{KESIMPULAN}

Perbedaan konsentrasi $\mathrm{Cu}$ yang diberikan dalam media terhadap kandungan logam $\mathrm{Cu}$ pada Gracilaria sp. memperlihatkan semakin tinggi konsentrasi $\mathrm{Cu}$ yang diberikan, maka kandungan logam Cu pada Gracilaria sp. meningkat. Lamanya waktu pemaparan oleh $\mathrm{Cu}$ mengakibatkan pertumbuhan Gracilaria sp. terganggu sehingga menyebabkan kematian. Pertumbuhan Gracilaria sp. pada media yang mengandung $\mathrm{Cu}$ dengan konsentrasi yang berbeda memperlihatkan semakin tinggi konsentrasi $\mathrm{Cu}$ yang diberikan maka pertumbuhannya akan menurun. 


\section{DAFTAR PUSTAKA}

Angkasa, W.I., Purwanto, H. \& Anggadireja, J.T. 2011. Teknik Budidaya Rumput Laut. Penebar Swadaya, Jakarta.

Atmadja, W.S., Susanto, A.B. \& Dhewani, N. 2012. Pengembangbiakan Rumput Laut (Makroalgae). Penerbit IFI. Jakarta.

Das, N., Vimala, R. \& Karthika, P. 2008. Biosorption of Heavy Metals. an Overview. Indian Journal Biothecnology, 7:159-169.

Davis, T.A., Volesky, B. \& Vieira, R.H.S.F. 2000. Sargassum Seaweed as Biosorbent for Heavy Metals. Journal Water Research, 34(17):4270-4278. DOI: 10.1016/S0043-1354(00)00177-9.

Davis, T.A., Volesky, B., \& Mucci, A. 2003. A Review of the Biochemistry of Heavy Metal Biosorption by Brown Algae. Journal Water Research, 37: 4311-4330. DOI: 10.1016/S00431354(03)00293-8.

Elawati, Kandowangko, N.Y. \& Lamondo, Dj. 2016. Efisiensi Penyerapan Logam Berat Tembaga (Cu) oleh Tumbuhan Kangkung Air (Ipomoae aquatica Forks) dengan Waktu Kontak yang Berbeda. Jurnal Peradaban Sains,,6(2):162-166.

Figueira, M.M, Volesky, B., Ciminelli, V.S.T. \& Roddick, F.A. 2000. Biosorption of Metals in Brown Seaweed Biomass, Journal Water Research, 34(1):196-204.

Ihsan, Y.N., Aprodita, A., Rustikawati, I. \& Pribadi, T.D.K. 2015. Kemampuan Gracilaria sp. sebagai Agen Bioremediasi dalam Menyerap Logam Berat Pb. Jurnal Kelautan, 8(1):10-18.

Lestari \& Edward. 2004. Dampak Pencemaran Logam Berat terhadap Kualitas Air Laut dan Sumberdaya Perikanan (Studi Kasus Kematian Massal Ikan-Ikan Di Teluk Jakarta). Jurnal Sains, 8(2):52-58.

Nasuha, T., Yuliani, \& Indah, N.K. 2014. Efektivitas Gracilaria gigas sebagai Biofilter Logam Berat Timbal (Pb) pada Media Tanam. LenteraBio : Berkala IImiah Biologi, 3(1):91-96.

Nduka, J.K. 2012. Application of Chemically Modified and Unmodified Waste Biological Sorbents in Treatment of Wastewater. International Journal of Chemical Engineering, DOI: 10.1155/ 2012/751240.

Raya, I. \& Ramlah. 2012. The Bioaccumulation of Cd (II) lons on Euchema cottonii Seaweed. Marina Chimica Acta, 13(2):13-19.

Rodenas de la Rocha, S., Sanchez-Muniz, F.J., Gomez-Juaristi, M., \& Marin, M.T.L. 2009. Trace Elements Determination in Edible Seaweeds by an Optimized and Validated ICP-MS Method. Journal of Food Composition and Analysis, 22:330-336. DOI: 10.1016/j.jfca.2008.10.021.

Samsundari, S. \& Perwira, I.Y. 2011. Kajian Dampak Pencemaran Logam Berat Di Daerah Sekitar Luapan Lumpur Sidoarjo Terhadap Kualitas Air Dan Budidaya Perikanan. Jurnal Gamma, 6(2):129-136.

Simatupang, L., Oktavia, D.P. \& Doloksaribu, M. 2017. Adsorpsi Logam Berat Pb (II) oleh Adsorben Berbasis Silika dari Abu Vulkanik Gunung Sinabung. Jurnal Pendidikan Kimia, 9(2): 330-335. DOI: 10.24114/jpkim.v9i2.7682.

Suardika, N.B.A., Atmaja, B.T. \& Deseliane, S. 2017. Pemanfaatan Kappa-Karaginan dari Rumput Laut Merah (Eucheuma cottonii) sebagai Bahan Solidifikasi dan Stabilisasi Logam Berat Chromium pada Limbah Tekstil. Dalam: Seminar Nasional Peranan Ipteks Menuju Industri Masa Depan (PIMIMD-4) Institut Teknologi Padang, 27 Juli 2017, Padang, pp. 10-16.

Supriyantini, E., Gunawan, W.S. \& Ladies, N.A. 2018. Pertumbuhan Rumput Laut Pada Media Yang Mengandung Tembaga (Cu) Dengan Konsentrasi Yang Berbeda. Jurnal Buletin Oseanografi Marina, 7(1):15-21.

Widyorini, N. 2010. Analisis Pertumbuhan Gracilaria sp. di Tambak Udang Ditinjau dari Tingkat Sedimentasi. Jurnal Saintek Perikanan, 6(1):30-36.

Yong, W.T.L., Chin, J.Y.Y., Thien, V.Y. \& Yasir, S. 2017. Heavy Metal Accumulation in Field Cultured and Tissue Cultured Kappaphycus alvarezii and Gracilaria changii. International Food Research Journal, 24(3):970-975.

Yulianto. B., Ario, R. \& Triono, A. 2006. Daya Serap Rumput Laut (Gracilaria sp) Terhadap Logam Berat Tembaga (Cu) Sebagai Biofilter. IImu Kelautan: Indonesian Journal of Marine Science 11(2):72-78. DOI: 10.14710/ik.jjms. 11.2.72-78. 